\title{
THE CHURCH AND TOTALITARIAN DEMOCRACY
}

\section{JOHN COURTNEY MURRAY, S.J.}

\author{
Woodstock College
}

ENRY H. WALSH opens his excellent study of the Napoleonic Con-
cordat with this statement:

The problem of Church and State as it unfolded itself during the negotiations for the Concordat of 1801 between the Pope and the French state was surprisingly novel to European diplomacy. It revealed a cleavage of opinion practically unknown in former attempts to reconcile things temporal and spiritual.... A new element had been intruded into this latest attempt to bring Church and State into harmonious relationship, making former endeavors to divide the fields of sovereignty seem almost simplicity itself. ${ }^{1}$

The "new element" was thrust into history, not by Napoleon, but by the French Revolution, and it was found wherever the Revolution went. If one understands this "new element," one has, I think, the key to an understanding of the nineteenth-century conflict between the Church and the Continental states. By the same token, one will have the key to an understanding of the architecture of the doctrine of the Church, as it developed in the course of the conflict, to find its most magisterial exposition in Leo XIII. It is as a background to a study of Leo XIII that I deal here with the new element in the Church-State problem.

However, such was the confusion of forces that led to the Revolution, and such has been the legacy of ambiguities left by it, that pamphleteers and polemists and even serious historians have long differed in their interpretations of this new element. Walsh calls it "nationalism, a revolutionary force, impatient of all traditional and venerable ideas of the essential unity of European thought and culture." ${ }_{2}$ More specifically, he defines the political essence of the new phenomenon as "state absolutism," had so firmly inculcated into the minds of the French people, the absolute unity of the state in all its aspects."

${ }^{1}$ Henry H. Walsh, The Concordat of 1801: A Study of the Problem of Nationalism in the Relations of Church and State (New York: Columbia University Press, 1933), Introduction, p. 11.
${ }^{2}$ Loc. cit.
${ }^{3}$ Ibid., p. 243.
${ }^{4}$ Ibid., Introd., p. 13. 
sovereignty, as Portalis, Napoleon's Minister of Ecclesiastical Affairs, made clear to the French legislature, entailed a firmly asserted supremacy of the political power over the spiritual, in such wise that the final sovereignty even in "mixed matters," which concern both Church and State, indisputably fell to the State. ${ }^{5}$

All this is true, as far as it goes. What Msgr. Spina, the representative of the Pope for the negotiation of the Concordat, met in Paris was a fierce trend towards the omnipotent state, towards an indivisible sovereignty within the state, towards the politicization of the whole of French social life, towards the enclosure of all institutions, including the Church, within the single framework of the nation under the single control of the public authority. But this multiple trend was not wholly new, save in its fierceness. It had already manifested itself in the absolutism, Gallicanism, and nationalism of the ancien régime, under which the freedom and spiritual independence of the Church had grievously suffered, and her international (better, supranational) authority had clashed with the claims of national sovereignty. Leo X had met the trend in its origins when he negotiated the Concordat of Bologna with Francis I. As Alexis de Tocqueville was the first to see, in respect of this absolutist trend the Revolution was in complete continuity with royal absolutism:

Even while Ranke was confirming to the King of Bavaria that the fundamental problem of the day was the conflict of monarchic with popular sovereignty, a keener mind than his saw in the politics of the time a deeper reality, a more pervasive trend. Alexis de Tocqueville saw the conflict of thrones and peoples as an incident, and underlying it all the relentless march of the centralized state towards the realization of its omnicompetent claims and the establishment of an irresistible government apparatus. He re-examined the history of the first French Revolution, and in 1855 published in a monumental work his conclusion that the revolution had not broken with the policies of the kings but had rather fulfilled them. Not popular sovereignty but centralization had been the achievement of revolutionary France; and as he looked out upon the Europe of 1855 he observed the same movement everywhere underway....6

The thrust of this movement had long been clearly directed towards the obliteration of all distinction between state and society, and to-

${ }^{5} \mathrm{Cf}$. ibid., ch. IV, for a study of Portalis.

- Quoted in Robert C. Binkley, Realism and Nationalism: 1852-71 (New York: Harper, 1935), p. 140. 
wards all the tyrannies that inevitably follow when this distinction is obliterated.

Absolutism and nationalism, and their historical accompaniment, a state-church, had long been a problem for the universal Church. But it was not an insoluble one until the Revolution added the really new element, by carrying the very foundations of the state to a new plane and claiming for it not only that measure of national and political autonomy which had made relations with the Church difficult during the era of royal absolutism, but also an entirety of spiritual and moral supremacy which made relations with the Church impossible. From the days when Francis I inaugurated what came to be known as the ancien régime, the Church had pushed the adaptation of her principles to the point of compromise, and had even pushed compromise to the point of scandal, notably in her consent to the absolutist demand for a national state-church, placed under royal surveillance and acting (as all state-churches more or less must act) as instrumentum regni, a source of ideology in support of a political form, as well as a sort of spiritual police to insure the preservation of that ideology in its purity.

But there comes a point beyond which concession and compromise cannot go; and it was reached early in the course of the Revolution. Since this is not properly an historical essay, it will suffice here to put the historical turning-point in the words of the "two essential affirmations" which Latreille accepts from the thesis of the great Jacobin historian, Mathiez: "The Revolution was not in its origins an enterprise of religious transformation directed against the national cult; but at a given moment in the course of the great crisis of the Terror the Revolution opposed to Catholicism new religious conceptions in irreducible antagonism to it." "To the absolutist program of the politicization of all social life, including religious life (begun with the Civil Constitution of the Clergy), was added a program of the dechristianization of France, its "laicization," as the Jacobin phrase had it. In addition to being the embodiment of an absolutist political theory, the state became the active vehicle of a secularist ideology that assumed the character of a religious faith, a faith as exclusive, as universal in pretension, and as exigent of total devotion as any religious faith. The Revolu-

'A. Latreille, L'Eglise catholique et la Révolution française (Paris: Librairie Hachette, 1946), p. 129. 
tionary purpose ceased to be purely political and undertook to be totally redemptive of man. And the One Indivisible Sovereign of Rousseauist theory assumed the messianic task of propagating his one true religion, first by a program of persecution and later, more insidiously, by a program of education.

The clash between Church and State in the nineteenth century was basically the clash between the Revolutionary purpose in its fully developed sense, of which the state was the agent, and the Christian purpose in its ancient traditional sense, of which the Church was the bearer. And the clash was as new as it was basic. Sturzo puts the matter thus:

The Church passed through three stages: that of the official cults (1789-95), that of separation (1793-1801), that of the Concordat (1801-14). In all three phases there were persecutions against the clergy as refractory, or non-patriotic, or nonimperial. In all three phases the Popes were involved: the occupation of Avignon and of Rome, the imprisonment of Pius VI at Valence (1798), of Pius VII at Savona (1809). Schism was no novelty for the Church, nor was the persecution of the clergy, nor the occupation of Avignon and Rome, nor the imprisonment and exile of Popes. What was new for the Church was the laicization of the power of the state. ${ }^{8}$

What was new was the fact that, as the secular historian, Geoffrey Brunn, points out:

For the first time in modern annals the civitas humana was set forth unequivocally as the ultimate reality in the place of the civitas Dei; for the first time the authority of reason was unblushingly acknowledged as superior to the authority of revelation, and the doctrine of human perfectibility (shortly to be reformulated as the doctrine of progress) was substituted for the doctrine of miraculous redemption. ${ }^{9}$

This was the final aspect of the new situation, which created that irreducible antagonism of which Latreille speaks. To the notion of integral nationalism, and to the further notion of the unity, indivisibility, and omnicompetence of political sovereignty, was added the idea of the nation-state as owing its origin and its authority solely to the will of man, as possessing a spiritual substance of its own, derived from no transcendental sources whatever, and as being the artisan of the only "salvation" there is, the earthly salvation of happiness and

${ }^{8}$ L. Sturzo, Church and State (London: Geoffrey Bles, 1939), p. 376.

' Geoffrey Brunn, Europe and the French Revolution: 1799-1814 (New York: Harper 1938). 
progress. Throughout its long history the Church had known more than one Caesar who had proclaimed himself to be God, or at least divine. Since Philip the Fair religious Caesarism had been an old story, and the Church knew every line of the plot. But she had never encountered a Caesar who proclaimed at once that he was the Divine Majesty and that his majesty in its origin and scope was wholly of the lay and secular order.

All the previous Caesars who had claimed divinity had sought the origin of their power in God and had at least to some degree shared what is God's special preoccupation, the eternal destiny of man, the salvation of his immortal soul. With them the Church could cope and even compromise; there was some common ground. Her main argument against them had been that it is no business of Caesar's to save man's immortal soul, but only to create on earth those conditions of freedom and justice which would assist the Church in this, her proper and exclusive task. But the Revolutionary Caesar took a wholly different line. He claimed divinity precisely because his origin was from man alone, and instead of simply using the religion of the state for his own political ends (which had been bad enough), he proclaimed his own political ends to be the religion of the state (which was intolerable).

In a word, the new event in political history, which lay at the root of the new Church-State conflict, was the apostasy of public power, in the Revolutionary concept of it, from the basic tenet of religious faith and political philosophy to which, in spite of whatever infidelities, it had always hitherto adhered: "Authority comes from God only, and all authorities that hold sway are of his ordinance" (Rom. 13:1). Debidour, the brilliant anticlerical historian of the Church-State conflict, puts the essence of the new state of affairs when he explains why the Church which had been friendly with the Gallican absolutism of the ancien régime was hostile to the Revolution: "Since 1789 the solidarity which the same religious principle had formerly established between the Church and the state had no longer existed. It is no longer to God that our governments appeal when they claim the inspiration of the Revolution; it is to the people and to the people alone."'10

${ }^{10}$ A. Debidour, Histoire des rapports de l'Eglise et de l'elat en France de 1789-1870 (2nd ed.; Paris: Alcan, 1911), p. 639. 
No one who is familiar with Jacobin jargon will misunderstand what a Jacobin historian means when he speaks of "the people"; he means, of course, the sect of the Jacobins, the political heirs of the philosophes. The Jacobins are "the people," in that they are the vanguard of the enlightened, the hierarchy of the elect, the depositaries of the Rousseauist "general will" whose sharing constitutes a people, the prophets of "the general interest" which is the interest of the people, the makers of the laws whereby a people is formed. It is essential to understand this point, if one is to understand both the new "enemy" which appeared with the Revolution and the structure of the Church's doctrinal and tactical opposition to him.11

In such a complicated historical matter as this, one hesitates to simplify; nonetheless it is necessary to achieve some simplicity in order to define the basic issues in the conflict between the Church and the Revolution. One may therefore say that, insofar as the Revolution was the enemy of the Church (and it was many other things besides this), the Revolution was in effect Jacobin sectarianism, as a set of ideas and as a sociological force. The Revolutionary purpose, insofar as it was directed against the Church, was the Jacobin purpose. It is therefore important here to note the two salient features of the Jacobins: first, they were a sect with a religious purpose, which was to make of the nation a new spiritual community, informed by their own faith; $;^{12}$ second, they were a party with a political purpose, which was to create the république une et indivisible, a totalitarian regime, standing in the exclusive service of their faith.

What de Tocqueville sensed without being able to define, Mr. Christopher Dawson, with a deeper insight born of later events, has clearly stated, namely, " . . the way in which the Jacobins anticipated practically all the characteristic features of the modern totalitarian regimes." ${ }^{13}$ These are now too familiar to us to need enumeration. The Jacobin democracy of 1793-94 was the first totalitarian state-this,

${ }^{11}$ Cf. A. Cochin, Les sociélés de pensée et la démocratie (Paris: Plon, 1920); this brilliantly written book gives an excellent account of the development of the Jacobin clubs out of the "philosophical societies," and of the role of the Revolutionary élite; among its other themes is that of "the two Frances" and the "two peoples," the Jacobins-and the others.

${ }^{12}$ The religious nature of Jacobinism and its ritualistic practices are minutely described in Crane Brinton's excellent study, The Jacobins (New York: Macmillan, 1930).

${ }^{13}$ Christopher Dawson, Beyond Politics (New York: Sheed and Ward, 1939), p. 71. 
as historians have begun to realize, was its major historical significance. This too was its essential significance for the Church. In fact, the contemporary intelligence can best understand the "new element" which the Revolution thrust into the Church-State problem by thinking of it in terms of totalitarianism. The Jacobin "solution" to the problem was a totalitarian solution; this was why the Church could not in any sense consent to it. Mr. Dawson says:

From our present point of view, however, the most important thing about this prototype of all our modern revolutionary and communitarian movements is that it also marks the decisive turning point in the relations between the state and the Christian Church. Although it finally resulted in the separation of Church and State, this was the very opposite of the ideal which it consciously aimed at. Its intention was to unite rather than to separate, to destroy the traditional dualism of the two powers and the two societies and to reabsorb the Church in the community. Nevertheless, this community was not a secular community in the strict sense of the word. The new Republic as conceived by Robespierre and St. Just and by their master Rousseau before them was a spiritual community, based on definite moral doctrines and finding direct religious expression in an official civic cult.... Thus the democratic community became a counter-church of which Robespierre was at once the high priest and the Grand Inquisitor, while Catholicism and atheism alike were ruthlessly proscribed. This was the boldest and most logical attempt to solve the problem of the relations of Church and state, or rather the relations of religion and society, that had been made since the Reformation. ... ${ }^{14}$

The totalitarian lines of this solution are very clear. Its cardinal assertion is a thoroughgoing monism, political, social, juridical, religious: there is only one Sovereign, one society, one law, one faith. And the cardinal denial is of the Christian dualism of powers, societies, and laws - spiritual and temporal, divine and human. Upon this denial follows the absorption of the Church in the community, the absorption of the community in the state, the absorption of the state in the party, and the assertion that the party-state is the supreme spiritual and moral, as well as political, authority and reality. It has its own absolutely autonomous ideological substance and its own absolutely independent purpose; it is the ultimate bearer of human destiny. Outside of this One Sovereign there is nothing. Or rather, what presumes to stand outside is "the enemy." Because the Church insisted on standing outside, the result was an irreducible antagonism. Insofar

${ }^{14}$ Ibid., pp. 72-73. 
as the Revolution was a doctrine and not merely an act or a fact (to use de Mun's famous categories), this was its doctrine - a monist, totalitarian doctrine. And all the clashes between the Church and the Revolution, whether in its republican and nationalist or in its imperialist and dictatorial phases, were secondary and subordinate to, and derivative from, this doctrinal conflict in which the opposing positions were irreconcilable. It was the ancient conflict between Pope Gelasius I and the Emperor Anastasius. It was the clash between the assertions: "Two there are...." and "One there is ...." Only now the terms of the issue were stated with a clarity and purity never before seen in history; for totalitarianism in the Jacobin style was something quite different from Caesarism in the Byzantine style.

A very recent book is of considerable use in confirming, as valid and correct, the foregoing statement of the Church-State problem in its new form. I mean J. T. Talmon's The Rise of Totalitarian Democracy. ${ }^{15}$ Its purpose is to show how out of the secular religion preached by the eighteenth-century philosophers there emerged a singular type of political and social order which, on the basis of its observed characteristics, deserves to be called "totalitarian." The author wishes this totalitarian democracy to be clearly distinguished from what he calls "liberal democracy." He is indeed clearly in error in stating, without further development, that this latter type "emerged from the same premises in the eighteenth century."16 If liberal democracy be taken to include the American realization, the error is demonstrable; but this is not the place for its demonstration. The point here is that he is correct, and in agreement with almost all political historians today, in distinguishing two historical types of democracy. ${ }^{17}$ And his analysis of totalitarian democracy, the issue of the Revolution, is documented in altogether convincing fashion. The book touches only lightly and incidentally on the clash between the Church and the new thing; but the description given of the thing itself makes abundantly clear why

15 Boston: Beacon Press, 1952.

${ }^{16}$ Ibid., Introduction, p. 1.

${ }^{17}$ It would be better to distinguish more than two; and the historical possibilities are happily not exhausted. The essential distinction is between democracies based on the Continental Liberalism of eighteenth-century origin, and those inspired by the liberal tradition, whose antecedents are longer, and importantly medieval and Christian. Only in his later work did Mr. Dawson come to see this distinction; cf. B. P. Schlesinger, Christopher Dawson and the Modern Political Crisis, Dissertation (Notre Dame, Ind., 1949). 
the clash was inevitable and irreconcilable, and what the issue was on which the clash occurred.

Talmon's basic contention - that Jacobinism, or totalitarian democracy, was the logical outcome of la philosophie, through the mediation of Rousseau's political theories-is, of course, not new. Hence only the essential outlines of his statement of the argument need be indicated. He says:

Eighteenth century philosophes were never in any doubt that they were preaching a new religion. They faced a mighty challenge. The Church claimed to offer an absolute point of reference to man and society. It also claimed to embody an ultimate and all-embracing unity of human existence across the various levels of human and social life. The Church accused secular philosophy of destroying the two most essential conditions of private and public morality, and thereby undermining the very basis of ethics. If there is no God, and no transcendental sanction, why should man act virtuously?18

The philosophes therefore accepted this "challenge to redefine the guarantees of social cohesion and morality." ${ }_{19}$ Their starting point was the idea of abstract, individual man, and thence they set out in "search for a new unitary principle of social existence," ${ }^{20}$ a new sanction for social ethics (it was only in consequence of their preoccupation with society and social order that they were at all concerned with religion).

The new principle was vague enough. But it was ordinarily expressed by the magic formula, "the natural order," or by the capitalized word, "Reason," which was the universal instrument for the complete discovery of the natural harmonious design of things entire, as also for the inevitable realization of this design in a social order that would be wholly rational, just, and blessed. The expectation of the advent on earth in full social fact of "the natural order" was truly messianic. And the main supports of this messianism were the belief in the natural goodness and rationality of man, and the consequent belief in the omnipotence of education, especially as accomplished by legislation: "Helvetius, Holbach, Mably, the Physiocrats and others, in the same way as Rousseau himself, believed that man was nothing but the product of the laws of the State, and that there was nothing that a government was incapable of doing in the art of forming men." ${ }_{21}$ The passage of these messianic philosophical ideas to the plane of a

${ }^{18}$ Talmon, op. cit., p. 21.

${ }^{19}$ Ibid., p. 22.

${ }^{20}$ Ibid., p. 18.

${ }^{21}$ Ibid., pp. 30-31. 
political system, equally messianic in pretension, was accomplished in terms of Rousseau's politico-religious system - his doctrine of the general will (which the people must be made to will, for it is their own latent will, and only in the willing of it do they achieve freedom), of the sovereignty of the state (which is as indivisible as the general will itself), and of the homogeneous nation (composed only of those who identify themselves with the general will and the general interest; those outside are not really of the nation). The passage from the philosophic to the political plane is thus briefly stated by Talmon:

The sole, all-embracing and all-determining principle of the philosophes, from which all ideas may be deduced, is transformed into the Sovereign, who cannot by definition err or hurt any of its citizens. Man has no other standards than those laid down by the social contract. He receives his personality and all his ideas from it. The State takes the place of the absolute point of reference embodied in the universal principle. ${ }^{22}$

Rousseau's sovereign is the externalized general will, and, as has been said before, stands for essentially the same as the natural harmonious order. In marrying this concept with the principle of popular sovereignty and popular self-expression Rousseau gave rise to totalitarian democracy. The mere introduction of this latter element, coupled with the fire of Rousseau's style, lifted the eighteenthcentury postulate from the plane of intellectual speculation into that of a great collective experience. It marked the birth of the modern secular religion, not merely as a system of ideas but as a passionate faith. ${ }^{23}$

The striking thing here is that Talmon, in situating the roots of totalitarian democracy in the two principles of rationalist individualism and political absolutism, is reiterating, with his own accent, the two propositions of the Syllabus which formulated, and condemned, the two basic articles of the new secular religion:

Proposition 3: Human reason, under no slightest regard of God, is the single arbiter of the true and the false, the good and the evil; it is a law unto itself, and of its own natural resources it is adequate to procure the well-being of men and of peoples.

Proposition 39: The state, inasmuch as it is the origin and source of all rights, possesses an authority that is without limits. ${ }^{24}$

The second proposition is pure totalitarianism; its condemnation was a vindication of the political freedom of the citizen. The first proposition

${ }^{22}$ Ibid., p. 19.

${ }^{23}$ Ibid., p. 43.

${ }^{24} D B$, nn. $1703,1739$. 
is the root of all secularist monism; its condemnation was a vindication of the spiritual freedom of man, which is rooted in the existence of a divine Reason in whose image man is made. And the two contrary assertions, implied by the two condemnations, are pregnant of the bases of the Christian dualism of laws and authorities at which totalitarian democracy struck: there are two orders of human life, and two authorities whereby they are respectively ruled. Each of these authorities acts by native right in its own field, and each of them, by reason of the inviolable distinction between them, is competent to limit the action of the other. It could be shown, were this the place to do so, that the preservation of this dualism in some functional form is the distinctive mark of true democracy as over against the totalitarian type. ${ }^{25}$

Talmon notes the fact that "totalitarian parties and regimes of the Left [i.e., of the "democratic" type] have invariably tended to degenerate into soulless power machines, whose lip service to their original tenets is sheer hypocrisy." ${ }_{26} \mathrm{He}$ does not pursue the reason for the fact, beyond suggesting two alternative possibilities. First, the degeneration may happen through "the inevitable process of corrosion which an idea undergoes when power falls into the hands of its adherents." ${ }_{27}$ But he adds: "Or should we seek the reason for it deeper, namely, in the very essence of the contradiction between ideological absolutism and individualism, inherent in modern political Messianism?" The question makes a wrong supposition, that there is a contradiction between eighteenth-century rationalist individualism and the ideology of political absolutism. Actually, the two ideas would seem to be inherently related. There is an internal link between secularist philosophic monism, to which the unidimensionality of rationalist

${ }^{25} \mathrm{Cf}$. Frederick Watkins, The Political Tradition of the West (Cambridge: Harvard University Press, 1948). It is the author's basic thesis that "Western civilization" began when "... the earlier view of society as a single homogeneous structure was replaced by the radically new idea of a twofold organization of society [Church and state]. With the possible exception of the concept of law itself, the concept of social dualism has done more than anything else to determine the character of Western civilization" (p. 32). He further maintains that this dualism is the fundamental protection of freedom (cf. p. 85, and passim), and argues at length that: "To preserve that dualism on the basis of purely secular institutions was the problem of modern politics" (p. 80). Whether or not the problem can be solved on a secular basis, whether or not a secularized society must inevitably become thoroughly politicized and monistic, remains to be seen.

${ }^{26}$ Talmon, op. cit., p. 7 .

27 Jhid., p. 8. 
individualism leads, and a political and social monism that is by inherent tendency absolutist and totalitarian. The transposition of the eighteenth-century rationalist principle into Rousseau's Sovereign did not occur by accident, or in consequence of the dissolution of some internal contradiction in the rationalist premises. It was an ineluctable logical process, the product of an inescapable dialectic, both intellectual and historical.

However, this has been a digression. More to our present purpose is Talmon's brilliantly accurate description of totalitarian democracy. The relevant parts of it may be briefly summarized under four heads. In each of them the monist principle is visible.

1) The first postulate is that there is only one plane of human life, the political. Man is simply a political creature; he wholly fulfills himself in being citizen. Politics embraces the whole of life. All thought and action are social in significance, and therefore are to be brought under political control. Here is the principle, not only of the primacy of the political, but of its exclusive, all-embracing character. To it was added the nationalist principle: the single framework of political life is the nation. There follows the principle of social monism: society is one, in the sense that it is to be absolutely homogeneous. Political parties, estates, all corporate bodies within society are disallowed; they are representative of "partial interests" (in the sense of Rousseau) and therefore destructive of the unity of society. Society therefore is composed directly of individuals, all absolutely equal; there are no social entities intermediate between the individual and the state. The state is monolithic; all non-conforming groups are to be eliminated. Finally, there is the principle of the indivisibility of sovereignty. Since there is only one general will and one general interest, sovereignty cannot be divided. This one, indivisible, unlimited sovereignty is to be exercised by the people, according to the principle of unanimity - a necessary principle in the light of the oneness of the general will. The unlimited sovereignty of the people is the sole source of law.

2) The second substantial element of totalitarian democracy is the principle that there is a sole and exclusive truth in politics. This is the eternal dream of the doctrinaire, that there exists, somehow objectively, a preordained scheme, harmonious and perfect, towards whose realization on earth all politics points. Here is the principle of all 
political messianism, which itself implies a certain social determinism: "the natural order" will be realized, because it must. (It is realized, always more perfectly, in the république une et indivisible, whose creation was in fact the Jacobin Revolutionary purpose in its political, and therefore primatial, aspect.) There is implied therefore a secular eschatology - the reign of les lumières in an order of perfect liberty, equality and justice, fraternity and bonheur. The absoluteness of this eschatological vision confers a primacy upon the Revolutionary purpose which looks to its realization, and therefore confers legality upon all Revolutionary means, including coercion and violence, which further the Revolutionary purpose. Moreover, the secularity of the vision forbids all manner of compromise with any forces that oppose the Revolutionary purpose. Since man is by nature good and rational, there can be no tolerance of evil or aberration in him. A secularist messianic monism must demand that the full demands of "virtue" be fulfilled on earth and the whole account of justice be settled in the here and now. There is no room for relativism in politics.

Upon the doctrine of the Revolutionary purpose there follows the doctrine of the role of the élite-in the case, the Jacobins. "The official dogma claimed that the Jacobins were the people. They could not possibly be regarded as a partial will, as just a party like other parties." 28 On the contrary, they are "the people," inasmuch as they embody the Revolutionary purpose and are the bearers of the one general will of the sovereign people. The people must be brought to will this general will; for only in willing the general will and sharing the collective purpose does their freedom consist. The people have to be brought to choose this freedom; if necessary they are to be forced to be free. Their freedom is really their equality in willing the general will; it is their total dependence on it.

3) Upon the doctrine of the state as an absolute objective value in itself, there follows the need for it to create for itself a social morality, a solely rational pattern of virtue, conceived in purely secular terms, completely independent of any transcendental reference. The social morality of totalitarian democracy must be absolutely homogeneous, like society itself, whose spiritual unity rests upon it. It must be obligatory on all, the single ethic of the state, of which the state itself is at ${ }^{28}$ Ibid., p. 128 . Cochin makes the same point. 
once the source and the sanction. The diffusion of this social morality throughout the whole social body makes the state a true spiritual community, a sort of quasi-church.

4) From this principle of the homogeneous social ethic underlying the homogeneous society, joined with the principle of unlimited state sovereignty (and therefore responsibility) there followed the principle of l'êtat enseignant. "If politics were to the eighteenth century a question of ethics, the problem of the rational and final social order was a question of attuning hearts." ${ }^{29}$ It is the right and duty of the state to spread les lumières, and to root out les préjudices (traditional religious beliefs which are heterogeneous to the spiritual substance of the new community). Men are to be imbued by the government with a virtuous sense of equality; their reason is to be perfected, their egoistic passions curbed. The "spiritual values" of the community are to be communicated to them; they are to be fused into the one collective entity, trained to will the one general will without any sense of constraint. In a word, the state is to "create a new type of man, a purely political creature, without any particular private or social loyalties, any partial interests, as Rousseau would call them." ${ }^{30}$ The tools for this task are, first, legislation, and second, the single state school.

Besides these four aspects of totalitarian democracy there is another that ought to be mentioned; Talmon touches upon it here and there. I mean the notion of "the enemy." "A Revolutionary government implies a war of liberty against its enemies." ${ }^{11}$ And Robespierre's catechism, after first asking, "What are our aims?", immediately asks, "Who are our enemies?" Actually, the very concept of totalitarian democracy automatically produces the enemy: "Depuis que le peuple français a manifesté sa volonté, tout ce qui est hors le souverain est ennemi," wrote St. Just, one of the great "Fathers" of the new ecclesia. ${ }^{32}$ (One recalls the Jacobin meaning of "the people.") The enemy, of course, is always the enemy of "freedom," of "public liberty," in the famous Jacobin phrase, meaning the dominance of the one general will of which the Jacobin sect was the bearer. Totalitarian democracy exists in a constant state of crisis; historians have pointed out what a decisive part in sustaining the Revolution in all its phases was played by the cry, "The Republic is in danger!" Robespierre put the situation,
29 Ibid., p. 141.
${ }^{30}$ Ibid., p. 42.
s1 Ibid., p. 118.
${ }^{32}$ Quoted ibid., p. 112. 


\section{or rather, the theory, with full fanaticism:}

Two opposite genii. . contesting the empire of nature are in this great period of human history interlocked in a mortal combat to determine irretrievably the destinies of the world, and France is the stage of this redoubtable struggle. Without, all tyrants are bent upon encircling you; within, all the friends of tyranny are banded in a conspiracy: they will go on plotting until all hope will have been wrested from crime. We have to strangle the internal as well as the external enemies of the Republic, or perish with her; and in a situation like this your first maxim of policy must be the guiding principle that the people shall be led by reason, but the enemies of the people by terror. ${ }^{33}$

Later, after the failure of terror, the great hope was put in education as a more subtle cord with which to strangle the Republic's internal enemy:

On the 27th Brumaire of the Year III, on the report of Lakanal, the Convention had voted for what we should call today the secularization of elementary education: religion was banished from the schools and replaced by a study of the Declaration of Rights, of the Constitution, and of 'republic morals.' Priests' dwellings not already sold were to serve as houses for teachers. It had proved impossible to destroy Christianity by force, and it therefore became an avowed part of the official program to destroy it by means of education, the diffusion of light, and by patriotism itself.... Thus the plan of substituting natural religion for Christianity was reaffirmed. Christianity could not be overthrown by violence. They hoped to do it by liberty and by strict legal restraints. ${ }^{34}$

The Revolution had a variety of enemies, of course; but none of them were more bitterly hated than the Catholic Church. And it was in the clash with the Church that the Revolution overreached itself: "No other factor was so fatal to the Revolution as the attack on the Church." ${ }^{35}$ Historical credits are difficult to assign, but it should be said, though it rarely has been said until quite recently, that to the Church belongs a major credit for having checked the rise of demo-

${ }^{33}$ Quoted ibid., p. 119.

"François Aulard, Christianity and the French Revolution, tr. Lady Frazer (Boston: Little, Brown, 1927), pp. 137, 139. Aulard is the prince of anticlerical historians. It is his judgment that, if the program of dechristianization by violence, launched in 1793, had been free to persist, it would have dealt the death blow to the Catholic Church in particular and to Christianity in general (cf. pp. 13, 121). The anticlericals of the Third Republic were equaly confident that the program of dechristianization by education would have the same result.

${ }^{35}$ Talmon, op. cit., p. 137. 
cratic totalitarianism in Europe. In the end the movement, for reasons not too difficult to understand, found its way to undisputed power in Soviet Russia, where the Church is still its most immovable spiritual opponent. There is visible historical continuity between the opposition of the Church to the totalitarianizing elements of the French Revolution and her opposition to the full-blown totalitarian system that emerged from the Russian Revolution.

The case made by the Revolution against the Church was substantially the case that had already been made by the philosophes. They had, of course, sought to disprove the Christian revelation as historically untrue. But their major indictment, taken up by the Revolution, was directed against the Church as a sociological force. The primary count bore on the "heterogeneity" of the Church to the unitary, homogeneous society envisaged by the philosophers: the Churchmeaning the universal Church, and in particular Rome-refused to allow itself to be reduced to a national society, or to be absorbed in the secular order. It insisted on maintaining its own distinct uniqueness as a society in its own right; it refused to accept the cardinal philosophical principle of the primacy of the political, and it firmly upheld the contrary principle of the primacy of the spiritual.

Throughout the eighteenth-century philosophical argument, as prolonged into the nineteenth-century political argument, there run the same two threads. First, in proclaiming a religious ethic founded on the sovereignty of God, heterogeneous to the naturalist ethic founded on the sovereignty of reason, the Church presumed to deny the totality of the claims of society upon the individual man. The Church would not accept the eighteenth-century secularist view that the moral drama is played out exclusively within the framework of human social relations, under the sole judgment of Reason, Nature, and the state. Religious faith and its moral ideal clashed with civisme, itself an exclusive faith, and its ideal of social morality. Catholicism as a faith was therefore deemed inimical to the spiritual unity and vitality of the community and to the cause of human progress of which the lumieres were the single, all-sufficient guarantee.

Secondly, what was more intolerable, the Church presumed to demand the right to exist as a sociological entity and a spiritual sovereignty within the state, but independent of the state and indeed 
superior to it. It presumed at once to be a structural element of human society and an element altogether heterogeneous to the political order. As such, it again violated the basic totalitarian principle of social unity. It refused to be subsumed under the one general will; it represented a "partial interest" destructive of the unity of the one general interest; it challenged the totalitarian claims of the One Sovereign. This was the line taken by Rousseau: "You cannot be a citizen and Christian at the same time, for the loyalties clash." ${ }^{36}$ The attack on the Church as proposing "imaginary" truths and a heterogeneous moral criterion was more characteristic of Voltaire and his heirs. In either case the clash was between the Church, as a faith and as a society, and the thoroughgoing monism of philosophical thought and Revolutionary politics. As a faith and as a society the Church was not "of the nation"; it was alien to the république une et indivisible. Consequently, it was the enemy.

Pius VI put an unerring finger on this vice of totalitarianizing monism in the first paragraph of his Allocution in a Secret Consistory on March 9, 1790:

At first, it was a question there [in France] of the order to be established in the public administration; and as the purpose was simply to lighten the burden on the people, the matter did not seem relevant to the concerns of our apostolic ministry. But from the task of establishing political order a step was suddenly taken to religion itself, on the ground that religion ought to be subordinated to political interests and made to serve them. ${ }^{37}$

The first formal condemnation of the Revolution bore upon its assertion of the primacy of the political, and implicitly upon the social and juridical monism which was the premise of this asserted primacy.

Again, this is the first count in the very lengthy indictment of the Civil Constitution of the Clergy made by Pius VI in the Brief, Quod aliquantulum, just a year later, March 10,1791. This Constitution was the first major step taken by the Revolution in the direction of the new Caesarism. It was not a fully self-conscious step, since its inspiration was.probably more Gallican than properly totalitarian. Nonetheless, the direction, if not the inspiration, was clear. The whole history of the

${ }^{36}$ Ibid., p. 22.

${ }^{37}$ Collection génerale des Brefs et Instructions de notre très saint Père, le Pape Pie VI, relatifs a la Révolution française (Paris: Le Clere, 1798), I, 2. 
ensuing century confirmed the correctness of Pius VI's discernment of the "basis and foundation" of the new state that was in process of being born.

Pius VII opens his indictment thus: "If one carefully reads the assertions of the Council of Sens, assembled in the year 1527 against the heresies of the Lutherans, it will be seen that the qualification of heresy must necessarily attach to that principle which is the basis and foundation of the National Decree in question." ${ }_{38}$ There follows a quotation from the Council which deals with the Defensor pacis of Marsilius of Padua, the editio princeps of which was published in $\mathbf{1 5 2 2}$ as part of the Protestant challenge to the Catholic Church:

As part of his hostile attack upon the Church, and of his impious flattery of the rulers of this world, he [Marsilius] denied to prelates all exterior jurisdiction, excepting that which the secular magistrate grants them. He further asserted that all priests - simple priests, bishops, archbishops, and even the Pope-are by the institution of Christ of equal authority; that if one is superior to another in authority, this happens in consequence of a free concession on the part of the lay ruler, a concession which he may at his own pleasure revoke. ${ }^{39}$

Against this doctrine the Council asserts the principle that "the ecclesiastical power does not depend upon the judgment of princes"; it is of divine law, and it is "not only superior but of greater dignity than any lay power whatsoever." 40

There was a certain genius in likening the principle underlying the Civil Constitution of the Clergy (which, as it developed, became the whole principle of the Revolution in religious politics) to the doctrine of Marsilius of Padua, "the first Erastian," as Sabine calls him, ${ }^{41}$ the first theorist to deliver a radical blow at the freedom of the Church. He represented the reaction to the extreme claims of hierocratic canonists, who stood for an absorption of the state within the Church; for his part, Marsilius wanted the absorption of the Church within the state. His solution was the opposite of that to which the logic of unity had led Boniface VIII: to Marsilius it was absurd to disrupt the unity of the state by admitting an independent Church, as it was monstrous

\footnotetext{
${ }^{38}$ Ibid., pp. 115-16.

${ }^{39}$ Ibid., p. 116.

${ }^{40}$ Loc. cit.

${ }^{41}$ George H. Sabine, A History of Political Theory (2nd ed.; New York: Henry Holt, 1950), p. 291.
} 
to Boniface to disrupt the unity of the Church by admitting an independent state.

In more than one respect Marsilius anticipated the principles of totalitarian democracy: "Whether it be in his criticism of the ecclesiastical institution, or in his theory of the 'usurpations' with which he reproaches the Church, or in his theory of her incompatibility with every notion of political or social order,... we find in him the genial announcement of the ideas which have been, and still remain, the permanent basis of the struggle waged by the laic City against the Church." ${ }_{42}$ Marsilius was the first to alter the very terms in which the Church-State problem had traditionally been posited since the days of Gelasius I and even before that: "The traditional 'Gelasian' principle of the distinction and co-operation of the two powers as necessary to the right government of the Christian world, which had provided the ground for such opposition to papal claims as that of Dante or John of Paris, is here openly challenged. Marsilius' whole effort can be said to be directed against this traditional duality...." 43 This is why Pius VII's allegation of the condemnation of Marsilius is so pertinent to his condemnation of the first tentatively totalitarian measure of the French Revolution. The error of Marsilius, as of the Revolution, was a monism, social, political, juridical. The basic Marsilian premise, derived from an Averroistic interpretation of Aristotle, was the unity of the state, as forbidding the organization of human life into two distinct societies, spiritual and temporal. Within this one state there is one sovereign, whose authority is absolute and all-embracing: "It admits of no limitation whatsoever. His 'sovereign' is not bound by the law of nature, and freely disposes of the law of God." 44 For (and this is the third characteristic) within the state there is only one law, the law of the state itself:

There is nothing left of the Thomist idea that the 'state,' however 'sovereign,' is subject to an eternal and absolute order of values, expressed in the body of divine and natural law. The state is the source of law, and its law has to be obeyed not only because it is the only rule endowed with coercive power, but because it is in itself the expression of justice. There is no place here for the Christian idea

\footnotetext{
${ }^{4}$ Quoted in A. P. d'Entrèves, The Medieval Contribution to Political Thought (Oxford University Press, 1939), p. 66; this is a brilliant essay on Marsilius.

43 Ibid., p. 73.

4t Ibid., p. 85.
} 
of divided allegiance, nor for the defense of fundamental values against the allpowerful will of the state... Law, which the Thomist had conceived as prior to the state, as both a condition and a limit of political power, now appears as the very creation of the state, as the outflow and test of its sovereignty. ${ }^{45}$

This juridical monism, as d'Entrèves had already pointed out, is the consequence of a particular theory of popular sovereignty, "a notion of the sovereignty of the 'general will' which reminds us even more of Rousseau than it does of Bodin or of Austin." 46 Within the Marsilian state, because of its postulate of unity, as Sabine says, "... there is no room for differences of jurisdiction or dispersion of power." ${ }^{47}$ The parallel with the Revolutionary theory is patent.

Equally obvious is the fact that Marsilius might almost be an eighteenth-century unbeliever in his concept of the place of religion within the state. Its sole value is its value for the well-being of the state:

... for Marsilius the religious functions of the priesthood have also a political basis. There is, in other words, a 'natural' foundation of priesthood as necessary to the state, independent of the truth of religion in itself. And even after the advent of the true religion, of Christianity, though the functions of the priesthood may have changed with relation to eternal life, with regard to the state and from the purely political standpoint, the value of the priesthood has remained the same: it is part of the political structure and subject to its laws. As such, the clergy, the pars sacerdotalis in the body politic, is entirely dependent on the government of that same body, that is, on the pars principans. It must therefore be regulated and controlled by the prince, and cannot possess, in any of its stages, any sort of coercive power. ${ }^{48}$

This concept of the political value of religion, joined to the concept of the unitary and absolute sovereignty of the state, led Marsilius to deny all possible independence to the Church, and degrade religion to a mere instrumentum regni. The same theory in substance underlay the Civil Constitution of the Clergy; it inspired Napoleon during the imperialist phase of the Revolution; it even furnished part of the motivation of the Law of Separation in the Third Republic. Though by that time another rationalist idea, likewise Marsilian in origin, was more to the fore - the notion of religion and of the law of God as having to do solely with the individual private forum of conscience,

${ }^{4}$ Ibid., pp. 63, 64 .

${ }^{47}$ Sabine, op. cit., p. 298.
${ }^{46}$ Ibid., p. 63.

${ }^{48}$ D'Entrèves, op. cit., pp. 68-69. 
as being singly relevant to eternal salvation, and altogether irrelevant to society and social action, which remain under the undivided control of the state.

D'Entrèves concludes his remarkable study of Marsilius with these words:

The Marsilian state remains as an illustration of what the state might have been, if, besides the Aristotelian influence, other and vital motives had not been contained in the legacy of medieval political thought, if new ideas and forces had not grown up from the very core of our Christian civilization to limit and neutralize the pretence of the state to embody the ultimate value of human life..$^{49}$

The essential new idea, that put a barrier to the somehow inherently totalitarian pretensions of the state, was, of course, the Gelasian thesis of the two powers and the two societies. Under a revival of pagan influences and ideas, under the spell of a myth of antiquity that presented to them the image of an all-enclosing, self-contained "republic of freedom and of virtue," the fathers of modern totalitarian democracy struck, in the first instance as in the last, at that central Christian idea. In this respect, their movement-like its heir, the Communist movement-was reactionary in the extreme, a reaction against the fifteen centuries of Christian civilization that had reposed on the Gelasian dualism of powers, societies, and laws which had been woven by Christian thinkers into the very substance of the "liberal tradition." In striking at this dualism they were striking at the last defence both of the spiritual freedom of the Christian man and of the political freedom of the people.

Since this was the central doctrine which the Revolution sought to deny in theory and cancel out of social fact, this was the doctrine which the Church thrust to the forefront of her teaching and action. The fact comes sufficiently clear through the first doctrinal pronouncement against the Revolution, Quod aliquantulum. The fact is visible likewise throughout the negotiations of the Concordat of 1801 and in the Church's subsequent protest against the Organic Articles. The focus of the controversy was somehow lost during the confusions of Pius IX's long reign; it is not clear in the thirty-two angry and sorrowful, and rather dreary, documents whence the Syllabus was culled; and the Syllabus itself was a discharge of scatter-shot aimed all over

49 Ibid., p. 87. 
the field at an enemy lurking behind every bush. But a new clarity came with Leo XIII. In his massive corpus all contemporary issues are touched; but the doctrine on Church-State relations which a total study of his writings will discover manifests a firmly structured form. And its basic architectural principle is the Gelasian thesis, developed to a new completeness and nicety of statement in the light of the new enemy brought on the world-stage by the Revolution.

The fundamental challenge of democratic totalitarianism to Christianity was its denial of the doctrine of a duality in the organization of society to which Gelasius I gave classic, though rudimentary, statement. Leo XIII and his advisers perceived this fact more clearly and fully than their predecessors. This is why his doctrine possesses sharp contemporary relevance, as well as abiding truth. Much of Leo XIII's writing is "dated," in the sense that it reveals accents appropriate to the nineteenth-century situation within which he spoke. ${ }^{50}$ But despite the decay and collapse of great sections of nineteenth-century Liberalism and its naive ideology, and despite the portentous alterations in today's spiritual and political climate, the focal point of Leo XIII's doctrine is likewise the focal point of the problem of the age in which we ourselves live. As D. W. Brogan has emphasized, the Age of Revolution has not yet run out; we are still living in it. ${ }^{51}$

In the light of the general problematic of the time, as heretofore described, I wish now to look at the doctrine of Leo XIII, using only Immortale Dei, and leaving to a later time a more inclusive study. Some brief account of the circumstances in which Immortale Dei was written is antecedently necessary.

Leo XIII became Pope in 1878. Bismarck was then straddling the

${ }^{50}$ One example might be Diuturnum (1881), On Civil Government. The basic thesis is the origin of public power from God, from which conclusions are drawn in two general lines, with the minor accent on the duty of the ruler to be just and fatherly, and the major accent on the citizen's duty of obedience, as a religious duty. In an age of revolutionary socialism, anarchism, unstable governments, and governmental hostility to religion, Pope Leo was saying to rulers (rulers were normally his chief addressees): You should welcome and support religion because it is the firmest support of strong government. In mid-twentieth century, when governments are altogether too powerful, the same premise would yield the same conclusions, but with the accents reversed: Since government is of God, it must observe the limitations and restraints put on it by the law of God, and respect the rights of the free human person which are rooted in that law.

${ }^{51}$ Cf. D. W. Brogan, The Price of Revolution (New York: Harper, 1951). 
turbulent international scene; Europe was full of political tensions, which the Congress of Berlin in that year did little to allay; so too were the Balkans and the Near East. Bismarck's policy of alliances was inaugurating the great era of power-politics. And on her part, the Church was in conflict with almost every government in Europe. The Kulturkampf in Germany, inaugurated in 1871 to effect the subordination of the Church, as of all other groups, to the sovereign power of the new Empire, was at its height; it was not to run out until 1883. A similar cultural struggle was being waged elsewhere. It was the heyday of the power-struggles between Left and Right, with the interests of the Church perilously allied to the uncertain destinies of the Right. In Italy the tragic impasse of the "Roman Question," big with all manner of unfortunate consequences, still persisted. In 1876 the fall of Minghetti had brought to an end the rule of the "enlightened conservatism" of the Right. There ensued the first ministry of the Left under the cynical Depretis, whose successor in 1887, Crispi, hardened the policies of his predecessor into a militant anticlericalism. Both Spain and Portugal were politically inconsequent, in the grip of the sterile policy of "rotavism," the alternation in office of Left and Right governments. And the Revolution as a doctrine was on the march in South America.

However, the main focus of events as of ideas was still France, the land of the Revolution, where the Revolution had entered upon a new phase, in the Third Republic. It had been proclaimed in accordance with accepted Revolutionary ritual at the Hotel de Ville in Paris on September 4, 1870; and it had received its customary baptism in the "Bloody Week" (May 21-28, 1871) of the Paris Commune. A year before the accession of Leo XIII the crisis of Seize Mai had undermined the government of McMahon, a monarchist, who supposedly was to prepare the way for a new restoration. A year after Leo's accession the crisis ran to its probably inevitable term in the resignation of McMahon and the establishment in power of the moderate Republicans, the Opportunists, as they were called. They had not the fanaticism of the Extreme Left, but as co-heirs of the Jacobin tradition they shared its fundamental positions: integral nationalism; the unity of sovereignty, which forbade the existence of autonomous units within society; a conception of sovereignty that was in theory 
and practice absolutist, and required the centralization of government and the suppression of all internal dissent; a theory of l'état enseignant and of the redemptive value of "Republican morality"; and, finally, in consequence of these principles, a commitment to anticlericalism as a principle of national government.

The anticlericalism of the moderate Republicans-of men like Gambetta, who became Premier in 1881, and of Ferry, the famous Minister of Education-was probably at bottom not different in quality from that of the Extreme Left. It was much of a piece with the anticlericalism of the Masonic lodges, which Courdaux, professor of literature at Douai, once defined by indirection:

The distinction between Catholicism and clericalism is purely official and subtle, for the needs of the tribune. But here in the lodge let us say aloud for the sake of the truth that Catholicism and clericalism are only one. And in conclusion let us add that one cannot be a Catholic and a Republican at the same time; it is impossible. ${ }^{52}$

However, the Opportunists were more willing to play with anticlericalism for reasons that justified their name:

The statements of Gambetta and Ferry, the testimony of their contemporaries, and the parliamentary situation all seem to indicate that anticlericalism was deliberately fostered by the Opportunists as a means of satisfying the radical element, while the social reforms for which they clamored were indefinitely deferred. ${ }^{53}$

It was the old Jacobin strategy of conjuring up "the enemy," as a means of consolidating power. As regards the permanent goal of Jacobin anticlericalism - what was called "separation of Church and state," and meant the dechristianization of society - there was little difference between the Left and the Extreme Left, save in what concerned the rate of speed with which the goal might be attained. The Extreme Left was for immediate abolition of the Concordat and immediate separation of Church and state. The Moderates were for proceeding to the same goal with some caution, after the advice of Arthur

${ }^{62}$ Quoted by Evelyn M. Acomb, The French Laic Laws, 1879-89: The First Anticlerical Campaign of the Third French Republic (New York: Columbia University Press, 1941), p. 115.

${ }^{53}$ Acomb, op. cit., p. 81. 
Ranc, Gambetta's adviser, a militant Jacobin anticlerical Mason, that ". . . it is necessary to proceed to it with persistence, breaking one by one all the bonds which unite Church and state, laicizing successively all public services," ${ }^{54}$ and at the same time preparing the minds of the masses by a program of Republican education.

So it was that, beginning with the two decrees of March 29 and 30, 1880 , two years after the accession of Leo XIII, there began the series of "anticlerical" laws which gave the cachet to this phase of the Revolution. ${ }^{55}$ The first two laws were directed against religious associations: the Jesuits were to be dissolved and dispersed within three months, and other teaching associations within six months. By 1881 the Opportunists had secured the enactment of laws for the establishment of primary normal schools to train secular teachers (obviously along Republican lines), for the removal of priests from the administration of charities, for the suppression of degrees from Catholic faculties, for the elimination of bishops from the higher council of education, for the abolition of the practice of allowing nuns to teach simply on presentation of letters of obedience from their superiors, for the secondary education of girls, and for the reduction of the number of chaplains in the army.

In the five years after Gambetta became Premier, and before the Boulangist crisis halted the program, the body of "anticlerical" legislation was further augmented, beginning with the famous measure of Ferry (March 29, 1882) which made education from the years 6 to 11 free, compulsory, and "neutral," under abolition of all religious instruction in state schools. On July 27,1884 the bitterly contested law re-establishing divorce was enacted, under repeal of the law of 1816. In addition there were laws for the protection of civil funerals, for the non-observance of religious holidays, for the secularization of cemeteries, for the freedom of the press from all religious restrictions, for the delimitation of the functions of vestry and commune, for the removal of religious orders from primary education, and for the compulsory military service of members of religious orders and students for the priesthood. The Panthéon was secularized, public prayers for

${ }^{54}$ Quoted ibid., p. 151.

${ }^{55}$ The summary given here is taken from the complete and detailed study done by Acomb. 
the work of the legislative assemblies were abolished; and the Catholic faculties of theology were suppressed.

This legislative program did not indeed satisfy the Extreme Left, which would be content with nothing less than "separation of Church and state" in the Jacobin sense; but it was sufficient evidence of the fidelity of the government to the programmatic utterance of Mirabeau in the earliest days of the Revolution: "Il faut décatholiciser la France." Behind the program, as its chief motivating influence, lay the resurgence of the totalitarian ideology of the Jacobins, of their secular religion of patriotism, and of their hope to make patriotism the religion of France, under final destruction of Catholicism.

In 1885 , when this antireligious, totalitarianizing program was in full swing, Leo XIII issued Immortale Dei, De civitatum constitutione christiana, On the Christian Order of Society. The Encyclical contains two things: first, a sketch of the historical enemy in view at the moment, a new type of religio-political order inspired by a particular philosophy and animated by a particular ethos; second, a contrasting outline of the Christian politico-social order whose inspiration and ethos is quite different. I use the words "sketch" and "outline" advisedly. In writing an encyclical the Pope is not a scholar; he is exercising the Church's supreme prophetic and pastoral ministry. Hence one does not look in papal encyclicals for detailed analyses of systems of thought, for full-fleshed reconstructions of historical eras, ${ }^{56}$ for a sophisticated delineation of the historical movement of ideas. ${ }^{57}$ Destined as they are for all the faithful, encyclicals deal in basic simplicities; they are done in the prophetic, not the academic, manner. The colors are the black and white of truth and error, not the ambiguous gray of history.

${ }^{56}$ Thus the section, "Fuit aliquando tempus...," on the Middle Ages is not history properly so called; the description of the harmony then prevailing leaves out the many bitter and damaging quarrels of Popes and emperors. More exactly, the Pope is making a moral judgment on history: "The medieval relation of the two powers was A Good Thing." This moral judgment, it need hardly be said, does not imply a canonization of the medieval situation as somehow an ideal.

${ }^{57}$ Thus the rapid and unilinear derivation of the political Revolution from the philosophical revolution, and of the latter from the religious revolution, is not Ideengeschichte in the proper sense. Nineteenth-century laicism had important roots in the late Middle Ages; and the revolution against the ancien régime was directed against the royal absolutism whose roots were not in the Reformation but in the Renaissance revival of antiquity. 
Immortale Dei therefore is not a scholarly dissertation, broad of scope, careful of nuance; it is a tract for the times, confined in its outlook, concerned with an historical situation. One may not look in it for an organic statement of the whole of Catholic political and social philosophy; for instance, it neglects completely the distinction between "society" and "state" which is of the essence of that philosophy; for another instance, the discussion of the sovereignty of the people is wholly inadequate for scholarly purposes. Similarly, one may not regard the Encyclical as a full discussion, doctrinal and historical, of the Church-State problem; it is simply concerned with the iniquitous historical situation evoked in the Latin, and traditionally Catholic, countries of Europe, notably France, by the religious, political, and social ideology of the Revolution. There is little, if any, advertence to the significantly different situation in Bismarck's Second Reich. And any reference to the almost totally different situation in the United States is wholly absent. The Roman advisers of Leo XIII knew their Rousseau; they had probably never heard of the Federalist papers. It is indeed a curious paradox that, at a time when the Roman curia was intensely preoccupied with problems of political realizations and the philosophy behind them, they had apparently no interest in the most striking and successful political realization of modern times, despite the fact that the philosophy behind it was of linear descent from the central political tradition of the West, which the Church herself had helped fashion out of Greek, Roman, and Germanic elements. ${ }^{68}$ It was in fact precisely the abandonment of this tradition in

${ }^{58}$ The Encyclical Letter, Longinqua oceani (1895), is not an attempt to evaluate the political genius of the American system. The Pope gladly recognizes the fact that the Church in America enjoys "tutam ... vivendi agendique sine offensione facultatem" (Leonis Papae, etc., VI, 15). But he does not pause to reflect on the uniqueness of the political structure that makes possible this security and freedom.

He goes on immediately to note an "error tollendus." The warning was timely and meant for European readers. Vatican policy in Europe was still pinned to the Concordat, to the theory of governmental favor and patronage as the necessary condition of the life of the Church. And the long search for this favor seemed just then to have been rewarded in the presidency of Félix Faure and the ministry of Méline in France. It was the beginning of the last flowering of "clerical republicanism." In two years the Dreyfus affair, and the unfortunate Catholic attitude towards it, would shatter the Ralliement and usher in the second great anticlerical campaign, which was to culminate in the abrogation of the Concordat and in the legislation of the 1905 Law of Separation. At the moment, however, the Ralliement seemed almost to have gone too far, in the direction of a rally to republican 
the era of absolutism, prolonged by the Revolution, that created the enemy which Immortale Dei confronted.

Immortale Dei therefore is frankly fragmentary, undisguisedly polemic, written with a very special enemy in view - an enemy with two facets, ideological and political. The ideological enemy is explicitly named: ". . the philosophy, sycophant of rulers." ${ }^{59}$ (Surely one of the more brilliant phrase-making efforts of the Pope's Latin scribes.) One might render it more flatly today by saying, "the philosophy which breeds totalitarianism." The political enemy, wherein this ideology is embodied, is likewise named, "a new kind of state." ${ }^{60}$ From the description given one may concretely translate, "the Third Republic of France, and any other national state which reveals its characteristics."

The Pope's description of the historical situation may be summarized as follows. We confront today a political phenomenon that is new in two respects. First, we confront a monist state, totalitarian in character. It identifies itself with society and pretends to be the highest,

principles. And Catholics were citing the American example, doubtless without understanding it. The Pope warns them against the error, "petendum ab America exemplum optimi Ecclesiae status" (loc. cit.). The error, of course, is not a proposition formulated by Americans. And any American would disavow it, for the same reason that he would accept the papal denial that "universe licere vel expedire, rei civilis reique sacrae distractas esse dissociatasque, more americano, rationes." The reason is that the American political system, as Gambetta said of French anticlericalism, was not conceived by its founders as an article for export. No more, therefore, is the American type of separation of church and state which is based on this political system. Moreover, the American Catholic does not pretend that the status of the Church in this country is "the best" for all possible situations. He is content to say that it is a good status, that it is grounded on good political principles, that its basis is not mere expediency, that it is not a makeshift to be endured pending the arrival of Catholics to the point of political power necessary to change it. The American Catholic might indeed say that the status of the Church is better than her status in a number of other places, e.g., better than it was in the Third Republic. But the adjective "best" when applied absolutely to a concrete political system is meaninglessespecially in the light of the sound Anglo-Saxon, and basically Catholic, principle of the relativism of political forms. Leo XIII concludes with the statement that the Church in America "would make far greater gains if, in addition to freedom, she were to enjoy the favor of the laws and the patronage of the public power." This statement is ambiguous. On the face of it, it would seem to be a statement of fact, not of doctrine, a manner of prophecy, an essay at history in the conditional mood. Yet it is hard to believe that the Pope was trying to play the role of the seer of history. The precise content of the proposition requires a careful and prolonged investigation.

${ }^{59}$ Leonis Papae XIII Allocutiones, Epistolae, Constitutiones, II (Paris: Desclée, 1887), 151.

60 Ibid., p. 164. 
indeed the sole, social form of human existence. It makes all other social forms of whatever kind, even the Church, dependent upon itself, and equal among themselves in this dependence. It assumes control over all public affairs, including religion and the institutions of human life traditionally regarded as sacred. It conducts all public affairs on the principle of the primacy of the political. It maintains itself to be the one Sovereign, as it is the one society. It recognizes no spiritual authority above or beside its own.

Secondly, we confront an apostate state, which is engaged in effecting by political and legal means the apostasy of traditionally Catholic society from belief in God and Christianity. It is expelling the Church from the rightful place of superior dignity which she has traditionally occupied in European society; it is stifling all Christian social institutions. It has adopted as the new religion of the state "the philosophy, sycophant of rulers." It is a philosophy which, in flattering the claim of individual reason to absolute and unlimited autonomy, flatters the claims of political power to totalitarian domination.

This philosophy asserts the absolute autonomy of the individual human reason. Each man is a law unto himself; and there is no higher law than that which he individually gives to himself. Thus the freedom with which reason endows him knows no limits. Everything is in principle permissible, a matter of individual choice. Even the decision to believe in God or not to believe in Him, to choose this religion or that, is a purely subjective matter. There is no objective order of obligations imposed on man; there is no one and nothing to create such an order. Man is bound to obey only himself.

In consequence of their possession of the attribute of reason, all men are by nature absolutely equal. In further consequence, there is no foundation in the nature of man for "authority," the right of one man to command another. There is by nature no such thing as "the political obligation," implying a distinction between rulers and ruled. No such distinction can exist among men who are by nature an absolutely egalitarian mass of absolutely autonomous individuals.

Society therefore, like the individual man, can only be ruled by itself, by "the people." What we call the state is, in fact as in right, simply the multitude, society, as master and ruler of itself. Moreover, the 
sovereign people is sovereign after the fashion of the individual. It is subject to no law that is not of its own making. Its sovereignty is indeed the source of all law and the root of all public power. And this public power is therefore as unlimited as the individual freedom of each man. As nothing escapes the control of individual reason, so nothing escapes the control of the state, the sovereign people.

Furthermore, this sovereign people, like the sovereign individual, since it acknowledges no authority higher than its own, no God therefore, does not worship. Or rather, it worships only itself. The statecult can only be the cult of the state, the worship of Reason, of the sovereign Will of the People, of the nation which is the people as invested with an historic revolutionary destiny. The individual man may, if it privately pleases him, believe in God and worship Him. But by definition the state, like the individual reason, knows no God. Again, individual believers may, if it so pleases them individually, band together into religious associations. But these corporate bodies do not exist by any native right; they can exist only by gracious concession on the part of the state, and are subject to governmental judgment on their benefit or danger to public order, to the spiritual and temporal welfare of that supreme community, both spiritual and temporal, which is the state. Only the state exists by native right, that is, by the sovereign will of the people. And the state is the source of all rights to social existences within it. As such, it has the power of final control over all the inferior social entities upon which it confers existence. Moreover, religious associations are no different in kind from any other type of corporate body existing within the state by favor of the state. This principle includes the Catholic Church. No more than any other corporation is it a society in its own right; and it may not claim any independent sovereignty, even spiritual. There is only One Sovereign, the state. And there is only one true religion, one religion of the state-the philosophy which is duly sycophantic of this One Sovereign.

This is the sketch of the enemy which Immortale Dei presents. My statement is merely a compilation, a developed paraphrase, which here and there makes explicit what is implied in the text, and occasionally uses a phrase taken from elsewhere in the Leonine corpus (so, for instance, the notion of social apostasy). It would be simple to docu- 
ment the statement. But these two texts will give the essence of the matter:

When the state is established upon such foundations as these (so much in favor in our day), one may readily see the situation into which the Church is forced, and how unjust it is. When governmental action is in harmony with these principles, the place in society accorded to the Catholic Church is on a par with, or even inferior to, the place granted to associations of quite a different nature. No account is taken of ecclesiastical laws. The Church, which must by the command of Christ teach all nations, is forbidden in the slightest way to touch public education. Civil officials on their own authority and at their own pleasure decide even those matters which are under a twofold jurisdiction [such as marriage and Church possessions]. In a word, they deal with the Church in terms of their own supposition, that she is to be deprived of the character and rights of a perfect society; they hold her to be entirely similar to all the other kinds of associations contained within the state. For this reason they maintain that all her rights and all her legitimate powers of action are possessed by her by the grant and grace of secular government. ${ }^{61}$

In this kind of political order, presently so much admired, it is a deliberate policy either to drive the Church wholly out of public existence or to hold her bound and fettered to the régime. The conduct of public affairs is in great part ruled by this intention. The laws, governmental administrative measures, the education of youth under exclusion of religion, the plundering and the destruction of religious orders, the overthrow of the civil dominion of the Roman Pontiffsall these things look to the same end; they are designed to put an end to the vigor of Christian institutions, to fetter the freedom of the Catholic Church, and to shatter all her remaining rights. ${ }^{62}$

One may therefore readily see the constitutio civitatum, the manner of social organization, against which the papal condemnation proceeds. It has two aspects. First, it is the political organization of society on the monist, totalitarian principle that the state is the highest and ultimate social form of human existence, which subordinates to its political control all other social forms, including the Church. Secondly, it is a socio-cultural organization of society on the basis of the secular faith of eighteenth-century rationalism, under forcible evacuation of European society's traditional Christian content, and under deliberate undermining of its Christian foundations.

In contrast, the Pope proposes the civilis hominum societatis christiana temperatio, the Christian organizing principle of civil society. It too has two aspects. First, it is an organization of society on the dualist

${ }^{61}$ Ibid., p. 157.

${ }^{62}$ Ibid., p. 158. 
principle of the two societies, two powers, and two laws, under observance of their distinction, the primacy of the spiritual, and the necessity for harmony between them in the interests of man's personal integrity and social peace. Secondly, it is such an organization of society as will ensure the Church the high dignity of her rightful place in society and the full freedom that is her native right, to the end that "the divine vigor and virtue of Christian wisdom [may] penetrate into social institutions, into the customs of the people, into all social classes and public affairs." ${ }^{63}$ Here again, as in the case of the condemned social order, it is a question both of a social structure and of a social ethos, of the spiritual substance of society as fashioned by Christian faith and morality, and of the political form of society as obedient to the demands of the dualism of Church and state.

The core of the Encyclical is the splendid statement of the ancient traditional doctrine of Gelasius I. The Pope lays the foundations for it by stating two propositions, one known by reason, the other by faith. First, human society is from God through the law of nature, as the necessary means and milieu of man's personal human perfection. The authority that rules society is likewise from God through the law of nature; and the political obligation - of rulers to the ruled, and of the ruled to their rulers - is basically a religious obligation. The foundations of society are in religion. Human society therefore owes a debt of religion to its Author, whose providence rules it.

Secondly, the Church is from God through the law of Christ, as a society in her own right, the necessary means and milieu of man's eternal salvation. Within the Church there is a spiritual authority, centered in her Head, the Roman Pontiff. And this spiritual authority has free command over the sacred things of Christ, His word and His sacraments, joined with the power to make laws, to judge and sanction their observance, and to administer freely and without hindrance whatever pertains to the Christian name and the Christian task.

From these two propositions the Pope immediately draws, as conclusions, the two leading principles of Christian social organization, the radical distinction of the two societies and the primacy and freedom of the spiritual:

This society, although it is composed of men, as civil society likewise is, is

1 Ibid., p. 155; the Pope points to this effect as the merit of the Middle Ages. 
supernatural and spiritual by means of the end appointed for it and by reason of the means whereby it pursues this end. For this reason, it is distinct from civil society and different from it. Most importantly, it is a society that is perfect in its kind and of its own right, since it possesses in itself and of itself by the will and grant of its Author all the aids necessary for its own well-being and action. As the end to which the Church moves is by far the most excellent, so also her authority is superior to all other powers; it cannot be held inferior to civil government or in any way subject to it. ${ }^{64}$

Accordingly, man's guide to his heavenly destiny must be the Church, not the state. It is to the Church that God has committed the function of vigilance and decision in regard of everything that concerns religion. She is to teach all nations and enlarge the horizons of Christianity as widely as possible. In a word, it is she who administers the whole Christian enterprise, with full liberty, on her own free judgment, and without hindrance. ${ }^{.5}$

There follows the most developed, detailed, and nicely balanced statement of the Gelasian thesis to be found in canonical sources; it is the central point of this Encyclical as of Leo XIII's whole body of teaching on the Church-State question:

Accordingly God has divided the government of the human race between two powers, the ecclesiastical and the civil. One of them is set in charge of divine things, the other of human things. Each of them is supreme in its own order; both of them are confined within certain limits, set by their respective nature and purpose. Hence there is a certain defined area in which each may act by native right. However, both powers rule over the same men, and occasions arise in which one and the same matter, in diverse ways, falls under the jurisdiction and judgment of both. In His providence, therefore, God, by whom both powers were established, had to mark out a course of action for each in right relation to the other. 'For all authorities that hold sway are of His ordinance.' Otherwise disastrous disputes and conflicts would frequently arise, and the individual man would often be troubled, and hesitate, like a traveller at a crossroads, uneasy about his course of action, when the two powers, neither of whose commands he can in conscience reject, issue contrary injunctions. Accordingly it is necessary that a certain orderly relationship should obtain between the two powers; not without reason has this relationship been compared to that by which soul and body in man are joined. What this relationship should be, and how far it should extend, can only be judged, as we have said, by reflecting on the nature of both powers. Regard must also be had of the excellence and nobility of their respective purposes, since the first and chiefest aim of one is to provide a sufficiency of earthly things, and of the other, to put heavenly and eternal goods within man's reach. Consequently, whatever is in any way sacred in human affairs, whatever has relation to the salvation of souls or to the worship of God-whether it be such by its own nature, or regarded

64 Ibid., p. 150.

${ }^{65}$ Ibid., p. 151. 
as such by reason of the end to which it is referred-stands under the authority and judgment of the Church. As for all other kinds of things, which fall into the categories of the civil and the political, it is right that they should be under the control of the civil authority, since Jesus Christ gave command that the things which are Caesar's are to be rendered unto Caesar, and the things which are God's unto God. ${ }^{66}$

I have elsewhere pointed out the newness of this formulation of the traditional doctrine, as over against the classic medieval statements. ${ }^{67}$ There are two new refinements.

First, the duality of societies is clearly marked, as well as the duality of powers; the medieval conception had been of two powers within the one society, the Christian commonwealth of Europe. This medieval notion had carried over in a debased form - debased through the loss of the universalist accent -into the era of royal and confessional absolutism, the era of national and territorial state-churches, that represented in principle a reaction to the pre-Hildebrand days of the Eigenkirchen. Doctrinally speaking, Leo XIII ended the threat to the freedom, transcendence, and universality of the Church that had been inherent in a confusion of the ecclesiastical and civil societies, of membership in the Church and citizenship in the state, of faith and nationality, of religion and politics, and in general, of the spiritual and the temporal. This confusion had marred the medieval pattern and revealed its historical immaturity; and the confusion had been particularly marked in the later Europe of the nation-states.

Moreover, the newly drawn clear distinction between the two societies put an end in principle to the medieval notion of the "secular arm," the notion of the instrumentality of political power to the proper spiritual ends of the supernatural society. The scope of the political power is confined to the ends of the political community as such; as Leo XIII says, secular government is not a $d u x$ ad coelestia. Moreover, in virtue of the distinct, and to that extent autonomous, character of the state as a society, the political problem is committed to the civic conscience (in a politically mature society, to the body of the people), and not to the ecclesiastical power; by the political problem I mean the primary question of the constitution, the fundamental law that defines the scope of the political obligation, giving legal

${ }^{66}$ Ibid., pp. 152-53.

${ }^{67}$ Theological Studies, X (1949), $220 \mathrm{ff}$. 
guarantee to the natural and civic rights of the citizen as citizen (who is such regardless of his religious condition), and setting limits to the exercise of governmental power. Leo XIII's distinction of the two societies lies at the root of one of his major emphases, upon the transcendence of the Church to political forms.

The second newness of the Leonine formulation of the Gelasian thesis lies in root from which Leo XIII derives the necessity of an "orderly relationship" between the two powers, namely, the fact that "the same man is both citizen and Christian." In the medieval conception the root of this necessity lay in the fact that the same one society was both Church and state. Leo's development is indeed eodem sensu, eademque sententia; but it is nonetheless a genuine development, from which consequences follow. Pius XII has to some extent drawn them. However, this matter must be left for future discussion.

My single purpose in this article has been to support the contention that the primary emphasis in the doctrine of Leo XIII falls upon his development of what I have called, for convenience sake and to denote its antiquity, the Gelasian thesis. ${ }^{68}$ The emphasis was called for by reason of the nature of the enemy, the monist totalitarian state that he confronted; it is therefore a polemic emphasis. But it is more than that. Actually, emphasis must fall on this dualist doctrine for intimately doctrinal reasons, apart from any polemic necessities. The fact is clear from the utter centrality of the two propositions on which Leo XIII bases his restatement of the thesis: civil society and the political authority that rules it are from God through nature: the Church and her spiritual authority are from God through Christ. From these two propositions he draws the three supreme principles that rule the relation between Church and state: the distinction of the two societies and their powers and laws, the primacy of the spiritual, and the need for harmony between them. This much certainly is doctrine, permanent and absolute. However, the doctrine was launched into history with the Church herself, with the result that today we

${ }^{68}$ There are seven documents of Leo XIII in which major statements of the Gelasian thesis are given: Arcanum (1880), Nobilissima Gallorum gens (1884), Immortale Dei (1885), Officio sanctissimo (1887), Sapientiae christianae (1890), Praeclara gratulationis (1894), Pervenuti (1902). In addition there are numerous shorter references. 
have treatises de iure publico. And the question is to know what in them is history, and what is still the doctrine. Before going into this difficult question, it is important to bring into central focus the indisputable doctrine.

Two other leading themes are found in Immortale Dei. The first is "freedom." The second is "public religion," meaning, I take it, the place of religion in the public life and action of society. The Encyclical treats this theme under two heads, public worship and public cura religionis, which latter is of two kinds, direct and indirect. I shall leave this second theme, public care of religion, for later discussion; it cannot adequately be dealt with apart from utilization of the whole Leonine corpus. Here, however, a few comments on the theme of liberty are appropriate.

It should be apparent that Leo XIII's condemnation did not fall on the "new kind of polity" because it embodied the principle and method of political freedom, insofar as they are an extension of the Christian doctrine of consent and its allied doctrine of popular participation in rule. On the contrary, the Pope affirms these ancient Christian political doctrines-briefly indeed, since their development was not to his purpose, but firmly enough. The new kind of polity was condemned because it embodied the principle of totalitarianism, the unitary character of society, the oneness of sovereignty, the primacy of the political. The main point of this article has been to clarify this fact, which unaccountably tends to get lost, not only in non-Catholic, but even in Catholic, interpretations of Immortale Dei.

For the rest, the enemy in view in the Encyclical is the rationalist concept of freedom as based on the absolute autonomy of human reason and the consequent absolute equality of all men. This concept is in fact but an aspect of the primary enemy, social monism. Rationalist theory pretended that the one and only organizing principle of social order is "freedom." It rejected the Christian principle of dualism, that there are two principles of social order, freedom and authority, which stand in a polar relation to each other. Leo XIII's essential point is that the monist theory can only lead "either to anarchy or to slavery"; 69 and in the light of subsequent experience hardly anyone would deny that he was absolutely right. We now know that social order does not

'9 Leonis Papae XIII, etc., II, 163. 
emerge out of "freedom" alone; freedom itself must be ordered by its polar principle, authority, operating through law.

The monist theory of freedom and order derived from another monism, the notion that society has its origin solely in the will of man - in a convention, the famous social contract - and not at all in nature. In contrast, Leo XIII proposes the Christian theory, again dualist: society originates both in nature and in the will of man. By nature man is a free person; also by nature he stands under social authority. And the principle of authority is equioriginal in nature with the principle of freedom. In other words, the political obligation, which implies at once the right to command on the part of the ruler, and a freedom of rational obedience on the part of the ruled, is an obligation rooted, as regards both its aspects, in the natural law. On the other hand, the concrete institutionalization of the political obligation is a matter of free choice on the part of the people. The natural law does not, in the abstract, dictate that the state should assume any particular concrete political form. It is for men to devise political institutions, both those through which the principle of social authority will operate, and also those through which the principle of personal freedom may express itself.

Leo XIII's concern is with these fundamental principles. In consequence, he is led to touch upon what seems to be a question of institutions, the "modern liberties," freedom of speech, the press, association, and religion. And his judgment is plainly adverse. His first view of these modern liberties falls upon them in a particular historical context, as they found place in the new type of polity that issued from the Revolution. And his judgment is adverse because the particular theory underlying the "modern liberties" in the monist state was false, because their dynamism was destructive in its direction, and because the concrete effects of their working were evil:

Beware of a superficial view, on which their specious appearance might deceive. Think rather of the principles from which they take their origin, and think too of the partisan purposes for which they are maintained and fostered. The effects they have had upon society are already sufficiently known from experience; they have had results which wise and honest men must rightly deplore. ${ }^{70}$

From the doctrinal point of view, the "modern liberties," as institu${ }^{70}$ Ibid., p. 164. 
tionalized in the new polity which the Pope has exclusively in view, are infected with the vice of their origin in the rationalist concept of individual autonomy. This false concept, made operative in society, cannot but lead "either to anarchy or to slavery," the intellectual anarchy that is consequent upon the dissolution of the common patrimony of Christian thought (upon which Leo XIII elsewhere lays stress), and the spiritual slavery that is consequent upon the dissolution, amid a welter of opinions, of the very idea of truth. Moreover, in what concerns "freedom of religion" and "separation of church and state," Leo XIII could not but have constantly in mind the fact that these institutions were not advocated in the new polity as genuine expressions of the principle and method of freedom, but as engines of war upon the Catholic Church. They were concretely part of the whole dynamism of the Jacobin movement. As such, they were "of the enemy," and hence as damnable as he.

It was not within the purview of Immortale Dei to consider whether these "modern liberties," including freedom of religion, could be projected on other than rationalist and Jacobin premises, and directed towards other than Jacobin purposes. Nor did the Encyclical face the fact that the principle of government by the people, radicated in the Christian democratic tradition, and altogether different in its resonances from the Jacobin "sovereignty of the people," somehow requires a polity characterized by "free institutions," as they are now called. Leo XIII was not called upon, in his context, to discuss the difficult question, how the dualism of freedom and authority, as necessary constituents of social order, finds application in the thorny matter of governmental control of those political processes whose freedom government is constitutionally called upon to protect.

At bottom, his single concern was to vindicate the principle that freedom, considered as antinomous to authority and not as complementary of it, cannot but lead either to anarchy or to slavery-or rather, necessarily to slavery, since anarchy is not a tolerable human condition. For the rest, Leo XIII was content to say that "an unbridled power to broadcast any idea one may have thought up is not among 'the rights of the citizen," " since it is not even among the rights of man; and that this kind of anarchic "freedom" is "not among the 
things worthy of favor and patronage," ${ }^{71}$ not because it is freedom but because it is anarchy, which is not normally an object of patronage. This, of course, is excellent sense. And there Leo XIII left the problem. It can hardly be said that he solved it in its full scope and in the form in which it was recently raised by Pius XII in his 1944 Christmas Allocution. Approval of government by the people (in a genuinely, not Jacobin, democratic sense) and of an active, vocal citizenry necessarily implies approval of those free institutions through which the people may give their judgment on the direction of political affairs and share in the direction and correction of governmental action.

"Ibid., p. 161. 